\title{
IAMJ
}

INTERNATIONAL

AYURVEDIC

MEDICAL JOURNAL

\section{A CONCEPTUAL REVIEW ON TREATMENT MODALITIES FOR RAKTAPRADAR W.S.R. TO DUB}

\author{
Himani Gupta ${ }^{1}$, Poonam Bamola ${ }^{2}$, Nikita Jaiswal ${ }^{3}$ \\ ${ }^{1}$ Assistant Professor, Dept. of PTSR, SGT University \\ ${ }^{2}$ Assistant Professor, Dept. of Shalakya Tantra, SGT University \\ ${ }^{3}$ Assistant Professor, Dept. of PTSR, SGT University, \\ Haryana \& Delhi NCR, and India
}

Corresponding Author: gupta.himani2103@gmail.com

\section{https://doi.org/10.46607/iamj1909122021}

(Published Online: December 2021)

Open Access

(C) International Ayurvedic Medical Journal, India

Article Received: 12/11//2021 - Peer Reviewed: 02/12/2021 - Accepted for Publication 16/12/2021

\section{Check for updates}

\begin{abstract}
Women are the pioneers and key to sustainable development and quality of life in the family. Hindu culture respects women as Goddess due to this power of creativity of life inside her womb. This energy of procreation starts with menarche and ends with menopause. Ayurveda focusses on preventive and curative measures of female health. Acharya Charak mentioned "Yonishu Shuddhasu Garbham Vindati Yoshitaha" i.e., normal healthy status of Yoni (vagina) is the key factor for achieving the conception. Various gynaecological disorders like Yoni Rogas, Artava Doshas and Raktapradar hampers the achievement of conception. Raktapradar i.e., excessive excretion of menstrual blood, either in quantity or in duration is explained in Ayurvedic Classics. It is the common cause of Iron deficiency anemia \& general debility. Ayurvedic intervention mentioned can be recommended as safer, feasible and effective therapy for management of Raktapradar.
\end{abstract}

Keywords: Shudha Yoni, Yoni Roga, Artava Dosha, Raktapradar. 


\section{INTRODUCTION}

According to Hindu culture woman is respected as Goddess due to the power of creativity of life inside her womb. Women perpetuate the next generation by creating and nourishing power. This energy of procreation starts with menarche. The menstrual cycle commences with this \& ends with menopause having normal menstruation depicts the wellbeing of females. Our women are the backbone of a healthy society.

Ayurveda has focused on preventive and curative measures of female health. Acharya Charak mentioned the normal healthy status of Yoni is the key factor for achieving the conception. Various gynaecological disorders i.e., Yoni Rogas \& Artava Doshas hampers the achievement of conception. Raktapradar is an abnormal condition and is not discussed under twenty Yonivyapad and eight Artavyapad, this is abnormal uterine bleeding and is commonly found in productive age group females. Raktapradar i.e., excessive excretion of menstrual blood, either in quantity or induration is explained in Ayurvedic Classics.

Raktapradar is the common cause of Iron deficiency anaemia \& general debility. It also causes psychological upsets like lack of concentration and discomfort in the workplace etc. The disease Raktapradar or Asrigdara explained in Ayurveda can be closely co-related with the condition of Dysfunctional uterine bleeding (DUB). Dysfunctional Uterine Bleeding (DUB) is a diagnosis of exclusion having the absence of structural or functional pathologies like benign or malignant neoplasms, or infections. It represents disorders characterized by dysfunction of the uterus, ovary, pituitary, hypothalamus or other parts of the reproductive system that results in abnormal or excessive uterine bleeding.

Almost all Ayurvedic classics highlighted the concept of Raktapradar which tells focuses on the importance given to the subject. In this study, we will aim for systemic complication and analysis with the interpretation of concepts of Raktapradar with a correlation of concepts of abnormal uterine bleeding from an Ayurvedic perspective.

\section{Aim and Objective}

To study conceptual literary review of Raktapradar along with Dysfunctional Uterine Bleeding in detail.

\section{Material and Method}

This conceptual study is extracted after reviewing all the available Ayurvedic classics as well as modern books thoroughly.

\section{Ayurvedic Description Definition:}

The Ayurvedic Classical view of the disease is defined by different Acharyas according to them Raktapradar and Asrigdar are stated as:

1. Acharya Charak said that Pradar is a disease in which blood comes in excess amount. He explained Raktapradar as a separate disease with its management in Yoni Vyapad Chikitsa, as one of the Rakta Pradoshaja Vikara ${ }^{3}$ and also under Pitta Avrita Apanavayu. ${ }^{1}$

2. Acharya Sushruta explained it as a separate disease entity in Shukra Shonita Adhyaya in Sharira Sthana. He also mentioned it under Pitta Samyukta Apana and in Rakta Pradoshaja Vyadhi ${ }^{2}$. Artava Vriddhi with their Nidana, Lakshana and Chiktisa have been described.

3. According to Vagbhata blood comes either during or intermenstrual period it is called Asrigdhar, Pradar or Raktayoni. ${ }^{3}$ Ashtanga Samgraha explained Raktayoni and said Asrigdara and Pradar as its synonyms.

4. Acharya Dalhana opined that even less amount of blood is seen during an intermenstrual period or if the duration of the menstrual period shortens, the disease is termed as Asrigdara.

5. According to Acharya Bhel when Shonita comes from the wrong path it is known as Pradar. It causes Shosha of the female body.

6. Acharya Madhav Nidan opinion was that when blood is discharged in an excessive amount from the vagina disease is known as Asrigdar.

Asrigdara excessive or prolonged flow of blood occurring in menstrual or intermenstrual period. ${ }^{4} \mathrm{By}$ the above views of different Acharyas it can be summarized that whether bleeding is scanty or increased or 
duration is short or long of an intermenstrual bleeding period, it is known as Raktapradar or Asrigdara.

\section{Nidana}

Acharya Charak has emphasized the importance of eating habits in the cause of disease. Acharya Sushruta described there is only an increased amount of blood loss during the intermenstrual period in Raktapradar. Madhav, Bhavamisra and Yogratnakar have described only the general aetiology of all types of Raktapradar. Acharya Madhav has added associated factors responsible for the disease.

1. Aahara (Dietary Habits) - Viruddha, Adhyashana, Ajeerna.

Samprapti (Pathogenesis):

Table 1: Samprapti Ghataka

\begin{tabular}{|l|l|}
\hline Dosha & Tridosha \\
\hline Dushya & Rasa, Rakta, Artava \\
\hline Agni & Jatharagni Mandhya \\
\hline Srotas & Rasavaha, Raktavaha \& Artavavaha \\
\hline Srotodushti & Sanga, Attipravritti \\
\hline Adhisthana & Garbhashaya \\
\hline Rogamarga & Abhyantara \\
\hline
\end{tabular}

2. Vihara (Lifestyle) - Yana, Adhva, Bhara, Abhighata, Atimaithuna, Divaswapana.

3. Mansika (Meantal Disorders) - Shoka (Rajo Guna Vriddhi--Vata-Pitta Prakopa-Asrigdara).

4. Anya (Others) - Garbhaprapat--Vata PrakopaAsrigdara.

5. Hareeta: Vandhya---Ksheera Naadi (Vatena Paripoorita) ---Kshire Cha Na Bhavet + Arthavam Cha Adhikam Yatah.

6. Bhel Samhita: Shonita--- Dusta Marga Pratipadyate---Prada. 


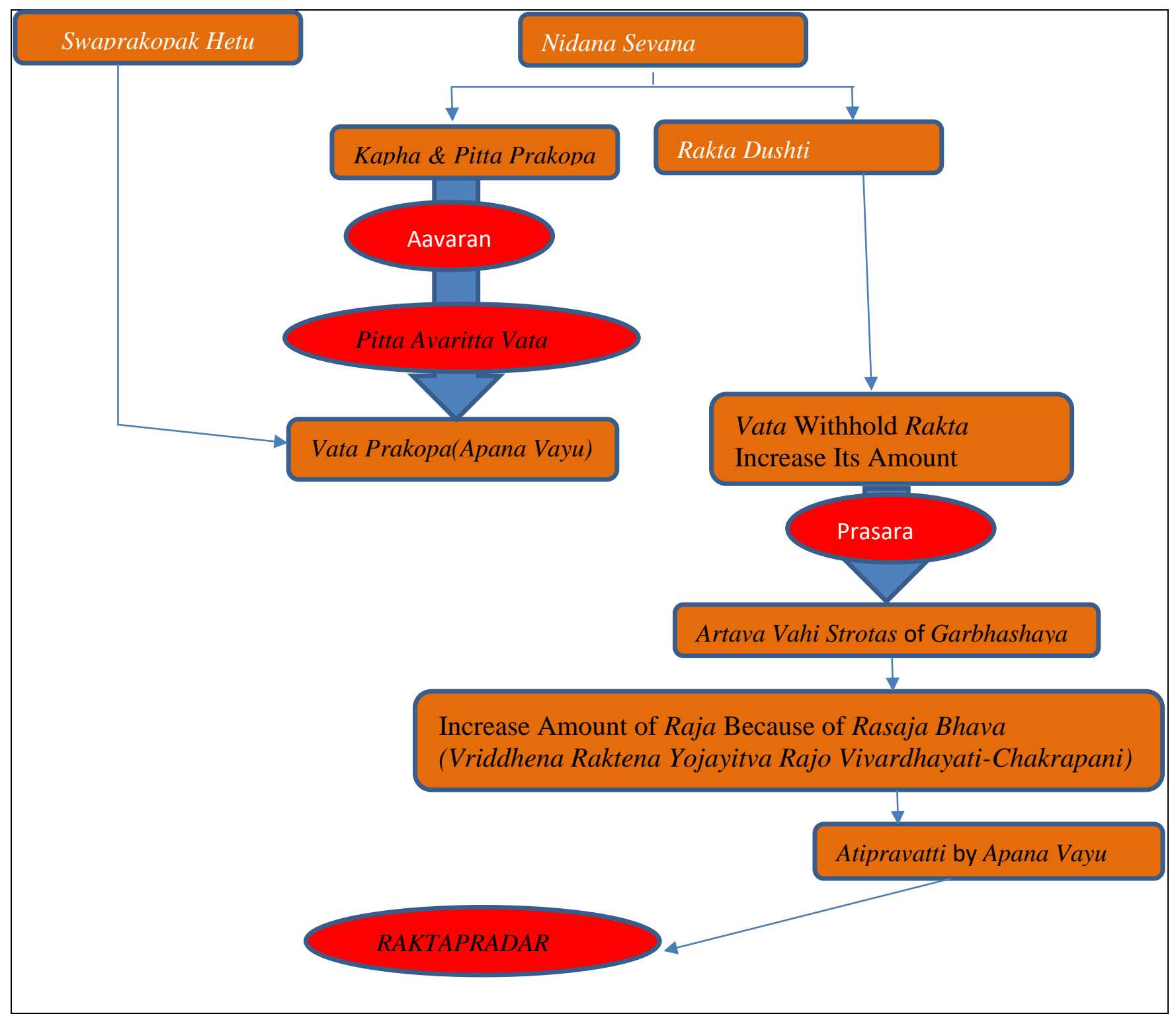

As per Ayurveda Samprapti of Asrigdara, we can be inferencing that Chala Guna of Vayu ${ }^{5}$ along with Sara ${ }^{6}$ and Drava Guna of Pitta plays an important role in forming the basic Samprapti of Asrigdara. Chala Guna is for increased movement and Saraguna disturbs stability and causes depletion of Dhatus (tissue). ${ }^{8}$ The pathogenesis clearly indicates that irrespective of aetiology, the pathology happens in Rajovaha Siras or endometrial vessels, this is realized today also. In DUB the main pathology lies in the vascular apparatus. (Jeffocate, 1975).
Classification: Acharya Charak, Madhav Nidan, Sharangdhara, Bhavprakash and Yogaratnakar have classified Raktapradar into 4 types. Acharya Susruta has not classified this disease. Acharya Dalhana has explained its clinical features according to the physical character of blood identical to those described in Venesection. ${ }^{9}$ Acharya Vagbhata has not given any classification, however, in treatment he has mentioned recipes of Vataja, Pittaja and Kaphaja Asrigdara. Commentator Indu just like Dalhana has stated that Asrigdara should be divided according to Doshas association, which is judged by the basis of features of blood described in venesection 
Table 2: Types of Raktapradar according to different Acharyas

\begin{tabular}{|l|l|l|l|l|l|}
\hline Author & Vataja & Pittaja & Kaphaja & Sannipataja & Dwandaja \\
\hline Charak & + & + & + & + & - \\
\hline Sushruta (Dalhana) & + & + & + & + & + \\
\hline Vagbhatta (Indu) & + & + & + & + & + \\
\hline Madhava & + & + & + & + & - \\
\hline
\end{tabular}

\section{Samanya Lakshana:}

Acharya Charak says the only symptom of Asrigdhara is excessive vaginal bleeding during menstruation. According to Acharya Sushruta in all types of Asrigdhara with excessive vaginal bleeding pain and body, the ache is present. Acharya Dalhan has mentioned that burning sensation in the lower groin region, pelvic part, backache and pain in flanks and severe pain in the uterus is a symptom of Asrigdhar. Vriddha Vagbhatta has described excessive bleeding during the menstrual or intermenstrual period as a symptom of Raktapradar. Acharya Bhavprakash, Madhav Nidan and Yogratnakar have described the same as in Sushruta Samhita i.e., body ache and pain in Raktapradar.

\section{Vishishta Lakshana:}

1. Vataja Raktapradar - Acharya Charak explains that in this condition discharged menstrual blood is frothy, thin, rough, and blackish or reddish or looks like washing of flower of Palasha in colour; comes with or without pain. This Vayu produces severe pain in the sacral, groin and cardiac region, flanks, back and pelvis.

Chakrapani explained that there is inter-menstrual bleeding in both Vataja Yoni Vyapada with Vataja Asrigdara. Acharya Sushruta also added that the blood flows quickly does not clot. Madhava Nidana, Bhav Prakasha and Yoga Ratnakara added that the menstrual blood resembles meat washing.

2. Pittaja Raktapradar - According to Acharya Charak in this type, the menstrual blood is blue, yellow or blackish, hot, comes in a profuse amount repeatedly with pain. It is associated with burning, redness, thirst, mental confusion, fever and giddiness.

Acharya Sushruta and Vagbhatta have mentioned that when vitiated by Pitta menstrual blood becomes blue, yellow, green, blackish and the colour resembles the water mixed with smoke or Rasanjana or cow's urine, musty or fishy in smell, being bitter not liked by ants or flies, does not coagulate because of its Ushnata. Madhav Nidana, Bhava Prakasha and Yoga Ratnakara added that gush of hot blood comes repeatedly with force and is associated with burning sensation and pricking pains.

3. Kaphaja Raktapradar - Acharya Charak explained that in this condition excreted menstrual blood is slimy, pale, heavy, cold, mixed with mucous and thick and is discharged with mild pain. Other symptoms like vomiting, anorexia, nausea, dyspnoea, and cough etc. may also be present. Chakrapani accepted the presence of features of Kaphaja Asrigdara in Kaphaja Yoni Vyapad and the presence of intermenstrual bleeding. According to Acharya Sushruta blood vitiated with Kapha Dosha looks like water mixed with Gairika (red ochre), is unctuous, cold, thick, slimy, is excreted very slowly and looks like a muscle after clotting. Acharya Vagbhata accepted the views of Sushruta, added that the menstrual blood resembles the flower of Kovidara in colour or it is pale, gets clotted in the shape of fibres, the flow stops at the opening of the wound, is salty and smells like fat.

Madhava Nidana, Bhava Prakasha and Yoga Ratnakara have mentioned that excreted blood is mixed with Ama and is slightly slimy, pale and simulates the washing of the paddy plant.

4. Sannipataja Raktapradar - According to Acharya Charak in Sannipataja Asrigdara clinical features of all the three Doshas are present. The discharge is foul-smelling, slimy, yellow and has acquired opposite properties. The blood is discharged with force. The Vasa (fat) and Meda (muscle fat) burnt with Pitta looks like the colour of Ghrita, marrow or muscle fat. The woman having such discharges 
continuously suffers from thirst, burning sensations, fever, anaemia and weakness. This type of Asrigdara is incurable.

Acharya Sushruta explained that the colour resembles that of Kanji and is foul-smelling. Madhava Nidana, Bhava Prakasha and Yoga Ratnakara mentioned that it resembles honey, Ghrita, Harital in colour, looks like bone marrow and has putrid smell.

Upadrava (Complications):

Acharya Sushruta stated following complications of Raktapradar - Daurbalya (weakness), Pralapa (delirium), Bhrama (mental confusion), Pandu (anaemia), Murchha (giddiness), Tandra (drowsiness), disorders of Vata Tama (feeling of darkness), Shotha (generalized oedema), Trishna (thirst) and Daha (burning sensation).

Acharya Madhava, Bhavamishra and Yogratnakara also told the same concept as above. Acharya Charaka said that Raktapradar is also an aetiological factor of Sotha. As we all know that continuous bleeding causes anemia and oedema occurs due to anemia.

Sadhya-Asadhyata (Prognosis):

According to all Ayurvedic classics, Sannipataja Asrigdara is incurable. Woman having continuous bleeding suffering from thirst, burning, fever, excessive blood loss (severe anemia) and weakness is incurable. ${ }^{10}$ the woman with very short intermenstrual period and continuous bleeding is incurable.

Chikitsa Siddhanta (Principle of Treatment):

Acharya Charaka explains the treatment just like Rakta Yoni i.e. Raktasthapana Aushadhis to be given due consideration to the association of Doshas. The patient should be treated online of Raktapitta \& treatment prescribed for Raktatisara, Raktapitta, Raktarsha, Guhyaroga and Garbhapata can also be used.

Treatment: The Principles of Ayurvedic management of Raktapradar can be grouped under the following headings-

1. Nidana Parivarjana: It means the identification of the causes, which are responsible for the pathogenesis of disease and avoiding them. ${ }^{10}$
2. Rakta Sthapana Drugs: Rakta Sthapana Dravyas explained by Acharya Charaka can be used in various preparations like Churna, Kalka, Swarasa, and Aasavarista etc. The line of management of Raktapitta disease can also be adopted in the condition of Asrigdara. ${ }^{11}$

3. Tikta Rasa: Tikta Rasa is advised with the following purposes $\bullet$ It pacifies the Pitta Dosha $\bullet$ To improve metabolism $\bullet$ As a coagulant.

4. Shodhana Chikitsa (Purification Procedures): As Asrigdara already causes Rakta Dhatu Kshaya, Mridu Shodhan Karma can be performed if it is very much required. Mainly there is vitiation of Vata Dosha, hence the use of Basti gives good relief. According to Acharya Kashyapa, Virechana can cure menstrual disorders because it is Pittaja and Raktaja disorders. Acharya Charak has suggested the use of Maha Tiktaka Ghrita for Virechana in Raktapradar.

5. Shamana Chikitsa (Internal Medications): Doshas, which are in Vriddhavastha are brought down to normal by various medicines explained in Ayurvedic texts in the management of Raktapradar.

Excessive bleeding per vagina leads to the poor general condition of the patient and if the general condition of the patient is poor, the patient cannot tolerate heavy treatment, so Raktapradara treatment depends upon the cause and general condition of the patient. So, treatment aims to stop bleeding immediately and to remove the cause. Acharya Charak in the treatment of Yoniroga has specified the treatment according to the predominance of Doshas.

a) Vataja Yoniroga - Snehan, Swedan and Basti Chikitsa.

b) Pittaja Yoniroga - Treatment advised for Raktapitta to stop bleeding and other treatment-related with use of Sheeta material.

c) Kaphja Yoniroga - Use of hot and dry materials and things.

d) Sannipataja Yoniroga-Treatment should be given according to the predominance of Doshas or mixed therapy can be given. 
Acharya Shusruta has mentioned Snehna and Basti according to Doshas, which is prevalent in the treatment of Yoni Roga. Internal Medications Used in Raktapradar:

- Kashayas: Darvaadi Kashaya, Dhataki \& Pooga Kashaya.

- Kalka \& Churna: Tunduleeyaka Mula with Honey, Rasanjana with Laksha Churna, Bala Mula Kalka with Milk, Indrayava Churna, Pushyanuga Choorna with Madhu \& Tandulodaka.

- Ksheera Prayoga: Ksheera Prayoga with Ashoka Valkala Siddha Ksheerapaka.

- Modaka: Alabu Phala Modaka.

- Avaleha: Kooshmandavaleha, Jeerakaavaleh.

- Ghrita: Brahat Shatavari Ghrita, Shalmali Ghrita, Sheeta Kalyanaka Ghrita, Shatavari Ghrita, Mahatiktaka Ghrita.

- Rasaushadhis: Pradararipu Rasa, Bolaparpati Rasa.

- Gutikas: Gokshura Guggulu, Chandraprabha Gutika.

\section{DYSFUNCTIONAL UTERINE BLEEDING}

Definition: Term 'Dysfunctional Uterine Bleeding' is irregular uterine bleeding that occurs in the absence of recognizable pelvic pathology, general medical disease or pregnancy. It reflects a disruption in the normal cyclic pattern of ovulatory hormonal stimulation to the endometrial lining. The bleeding may be excessively heavy or light and maybe prolonged, frequent or random was precisely used for excessive vaginal bleeding not associated with any genital tract abnormality, general or endocrinological disease.

In this case, hormonal imbalance is considered as the root cause of hyperplasia of the endometrium that causes menorrhagia. This usually happens in anovulatory cycles with the excessive or unopposed influence of oestrogen on the endometrium. Abnormal excessive bleeding may also occur due to abnormal endometrial haemostasis in some cases.

Causes: The causes can be classified as:

1. Organic Causes - Pelvic-Uterine Fibroid, Adenomyosis, Endometrial Polyps, Pelvic Infection in- cluding Chronic Endometrial Infection, Endometrial Hyperplasia, Copper Intrauterine Contraceptive Device, Uterine Vascular Malformation, Endometriosis.

2. Systemic-Coagulation disorder like Thrombocytopenia, Hypothyroidism, Hepatic, Renal and Cardiac Disease.

3. Iatrogenic - Anticoagulation therapy, Intrauterine Contraceptive Device.

4. Functional - In 40\%-60\% of women with Menorrhagia, no underlying cause is found.

\section{Classification:}

Abnormal uterine bleeding is of two types:

- Primary: Pathology in the endometrium or H-P$\mathrm{O}$ axis. It is of 2 types: 1 . Ovulatory 2. Anovulatory.

- Secondary: Pathology detected outside the H-PO-Endometrial axis like endocrinopathies, haematological, vascular disease, liver disorders etc.

- Iatrogenic: This is caused due to drugs like irregular intake of hormonal drugs, IUCD etc.

OVULAR DUB: In ovulatory cycles, progesterone production from the corpus luteum converts estrogen primed proliferative endometrium to secretory endometrium, which sloughs predictably in a cyclic fashion if pregnancy does not occur. Heavy but regular uterine bleeding implies ovulatory bleeding and should not be diagnosed as Abnormal Uterine Bleeding.

- Irregular Shedding of Endometrium -The abnormality is usually met in the extreme of the reproductive period. Normally regeneration of the endometrium is completed by the end of the 3rd day of menstruation, but in irregular shedding, desquamation is continued for a variable period with simultaneous failure of regeneration of the endometrium. It is due to incomplete $\&$ slow degeneration of the corpus luteum.

- Irregular ripening of Endometrium - In this there is the poor formation and inadequate function of the corpus luteum. Endometrium receives inadequate support of progesterone and breakthrough bleeding occurs before the actual bleeding occurs in a form of spotting and it is brownish in discharge. 


\section{ANOVULAR DUB}

It is the commonest cause of DUB. It is usually excessive. In the absence of growth-limiting progesterone due to anovulation, endometrial growth is under the influence of estrogen throughout the cycle. There is inadequate structural stromal support \& the endometrium remains fragile. Two varieties are found: -
- Puberty Menorrhagia - This is a threshold bleeding of adolescence caused by excessive or unopposed estrogen $\&$ the absence of progesterone in the anovulatory cycle.

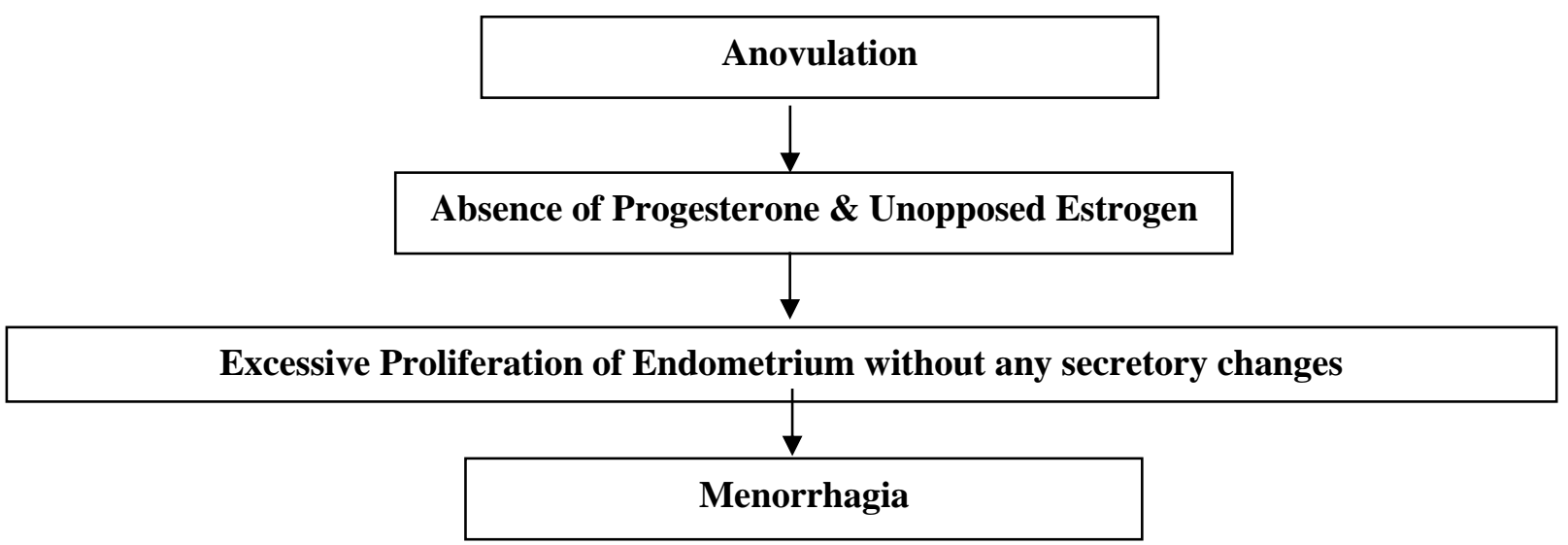

- Metropathia Haemorrhagica: This type of DUB is usually met in premenopausal women. The basic pathology may lie at the level of the ovaries or due to disturbance of rhythmic gonadotrophin secretion. There is a slow \& steady increase in estrogen levels with no inhibiting feedback effect of
FSH. As there is no ovulation, the endometrium is under the effect of estrogen \& there is the absence of growth-limiting progesterone for a prolonged period of corpus luteum.

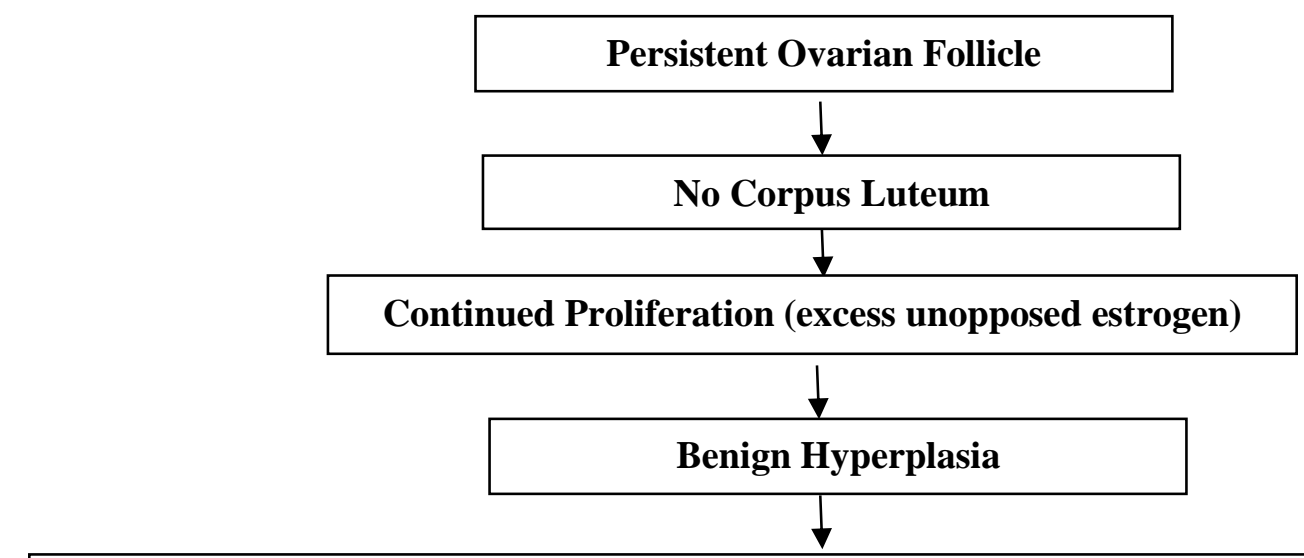

When Endometrium out-grows \& Blood supply Increases or Decrease in Secretions

\section{Heavy Bleeding}




\section{Diagnosis:}

Complete menstrual history, any emotional upset or psycho-sexual problem should be elicited. History of any abnormal bleeding from the injury site, epistaxis, gum bleeding to be enquired.

1. Blood investigation: $\mathrm{Hb} \%$, TLC, ESR, BT, CT, Platelet Count, TSH, T3, T4.

2. Endometrial biopsy: It is the most commonly used diagnostic test for DUB. It provides an adequate endometrial sample in $90-100 \%$ of cases.

3. Ultrasound: This can be used to examine the status of the endometrium, endometrial hyperplasia, endometrial polyps \& uterine fibroids. TVS is also very sensitive.

4. Hysteroscopy: This is done for better evaluation of endometrial lesions \& to take a biopsy from the offending site under direct vision.

5. Laparoscopy: This is used to exclude unsuspected pelvic pathology, such as endometriosis, PID \& ovarian tumour.

6. Hysterosalpingography (HSG): This is conducted to exclude fibroid, polyp or congenital malformation of the uterus.

\section{Differential Diagnosis of DUB:}

- Hormonal: PCOD, thyroid dysfunction, hormonal contraception.

- Pregnancy: Threatened/spontaneous abortion, ectopic pregnancy, post abortal endometritis.

- Local pathology: STDs, polyp, trauma, malignancy.

- Bleeding Diathesis: Platelet disorder, thrombocytopenia, Vit. K deficiency.

\section{Treatment:}

Treatment of DUB should be individualized according to age, parity, emotional and social background, severity, pattern \& duration of bleeding. Management should be directed towards - control of heavy bleeding, normalizing cycle, prevention of recurrence.

Measures of management of DUB are:

\section{General measures -}

When heavy bleeding is in progress patient should rest in bed and sedative may be given to allay anxiety.

- Dietetic errors and any cause for emotional upset should be corrected.
- Anemia should be treated according to type and degree.

2. Medical/conservative therapy -

- Hormonal: Estrogen, Progesterone, Combined OCPs, Androgens \& GnRH analogues.

- Non-Hormonal: NSAID (Non-Steroidal Anti-Inflammatory Drugs) \& Antifibrinolytic drugs.

- Selective oestrogen receptor modulators (SERMS): Clomiphene citrate \& Centchroman.

- Desmopressin, a selective analogue of arginine vasopressin can cause a rapid increase in Von Willebrand factor and factor VIII.

- Ethamsylate women with an anovulatory cycle require therapy that includes progestin. Regular, heavy menstrual bleeding can be successfully treated with both hormonal and non-hormonal options.

\section{Surgical Treatment -}

- Dilatation \& Curettage - It is done predominantly as a diagnostic tool for elderly women, but it has got therapeutic effect by removing necrosed and unhealthy endometrium.

- Endometrial resection/Ablation: This is done when women prefer to preserve her uterus; do not wish to preserve menstrual or reproductive function. The main complication being Asherman's syndrome. Hysteroscopic: Laser, Electro-surgery ablation Non-hysteroscopic: Thermal, ballon, Cryosurgery etc.

- Hysterectomy: It is the definitive treatment of DUB. When a patient is aged more than 40 years; conservative treatment fails \& blood loss impairs the general health of the patient, hysterectomy is indicated and can be done through abdominal as well as vaginal route.

\section{DISCUSSION}

Any abnormality in Rituchakra (menstrual rhythm) leads to excessive and irregular uterine bleeding which is known as "Asrigdara or Raktapradar" in classical text. Amongst various gynaecological disorders, irregular and/or excessive bleeding per vaginum is one of the commonest manifestations faced by a physician/gynaecologist. 
Inspite of tremendous advances in the field of diagnosis and treatment, at certain times the diagnosis of etiological factors of this type of bleeding is difficult because the psychology of the individual at a given particular time plays an equally important role in the causation of disease. These cases are then labelled as cases of Dysfunctional uterine bleeding or Asrigdara. In Ayurveda, Raktapradar can be correlated to Dysfunctional Uterine Bleeding.

Acharya Charak explained Raktapradar as a disease of vitiated Rakta and Pittaavrit Vata and Apan Vayu. Vyan Vayu is responsible for alteration in the ratio of endometrial prostaglandin and disturbance in the hypothalamus-pituitary ovarian axis (H-P-O axis). Disturbance in a uterine blood vessel may occur due to vitiation of Pitta Dosha. In the pathogenesis of Raktapradar, Chala Guna of Vata Dosha, Sara and Drava Guna of Pitta Dosha increase the amount of blood.

\section{CONCLUSION}

Raktapradar is a disease of the heavy menstrual cycle, which is characterized by excessive and/or prolonged bleeding per vaginum during menses or even in between the menses and is different from the features of normal menstrual blood.

Charak explained Asrigdara or Pradar as a separate disease with its management in Yoni Vyapad Chikitsa and mentioned it as symptoms of Pittavrita Apanav$a y u$. As it is known that without the influence of Vata Dosha, Yoni Vyapads never occur. In Asrigdara dominant causative factor or Dosha is 'Vayu' and Dushya is Rakta Dhatu.

Asrigdara or Raktapradar has a very close resemblance with the symptoms explained in dysfunctional uterine bleeding (DUB) of contemporary medical science. DUB is defined as excessive abnormal uterine bleeding where no organic pathology is known.

Various treatments prescribed in modern medicine like Hormonal pills, Antifibrinolytic agents etc. and hysterectomy have not proved their definite efficacy despite the high price, and side effects.

Therefore, despite a wide treatment option for its management which have multiplied over the recent years. Yet considering the factors such as age, parity \& wishes of the patient about contraception, future pregnancy etc, and the drug, which is nonhormonal, nonsurgical, and effective without any adverse effects is the need of the hour.

Ayurvedic texts have also described a variety of treatment options in the management of Raktapradar. Ayurvedic intervention mentioned above can be recommended as a safer, feasible and effective therapy for the management of Raktapradar.

\section{REFERENCES}

1. Charaka Samhita of Agnivesha, withVidyotini Hindi Commentary by Pt. Kashinath Shashtri and Dr Gorakhnath Chaturvedi Chaukhambha Bharati Academy Varanasi, Reprint-2007, Volume-2, Chikitsa sthana $28 / 230$.

2. 9 Sushruta's Sushruta samhita, Varanasi, Chaukambha orientalia, edition reprint 2011, Volume-1, Sutra sthana 24/9.

3. Vagbhatacharya, Ashtanga Sangraha with Hindi Commentary by Kaviraj Atridev Gupta, Krishnadas Academy, Varanasi, Reprint-1993, Uttar. 39/58,59,60.

4. Charaka Samhita of Agnivesha, withVidyotini Hindi Commentary by Pt. Kashinath Shashtri and Dr Gorakhnath Chaturvedi Chaukhambha Bharati Academy Varanasi, Reprint-2007, Volume-1, Chikitsa sthana 30/205-206.

5. Charaka Samhita of Agnivesha, withVidyotini Hindi Commentary by Pt. Kashinath Shashtri and Dr Gorakhnath Chaturvedi Chaukhambha Bharati Academy Varanasi, Reprint-2007, Volume-1, Sutrasthana 1/59.

6. Charaka Samhita of Agnivesha, withVidyotini Hindi Commentary by Pt. Kashinath Shashtri and Dr Gorakhnath Chaturvedi Chaukhambha Bharati Academy Varanasi, Reprint-2007, Volume-1, Sutrasthana a 1/60

7. Charaka Samhita of Agnivesha, withVidyotini Hindi Commentary by Pt. Kashinath Shashtri and Dr Gorakhnath Chaturvedi Chaukhambha Bharati Academy Varanasi, Reprint-2007, Volume-1, Sutrasthana a 1/60.

8. Dravya Guna Vijnana; Prof P. V. Sharma, Chaukhambha Bharati publications, Varanasi -221 001, (India), reprint 2008.

9. Charaka Samhita of Agnivesha, revised by Charaka \& Dridhbala, Elaborated Vidyotini Hindi Commentary by Pt. Kashinath Shashtri and Dr Gorakhnath Chaturvedi, Chaukhambha Bharati Academy, Varanasi, Reprint- 
2000, Volume-2, Chikitsa Sthana, Chapter-30, Shloka209.

10. Sushruta Samhita with the English translation of text and Dalhana's commentary along with critical notes, edited \& translated by Priya Vrat Sharma, Chaukhamba Vishwabharati, Varanasi, Vol-1, Reprint-2010, Uttara., Chapter-1, Shloka- 25.

11. Sushruta Samhita with the English translation of text and Dalhana's commentary along with critical notes, edited \& translated by Priya Vrat Sharma, Chaukhamba Vishwabharati, Varanasi, Vol-1, Reprint-2010, Uttara., Chapter-1, Shloka- 25.

\section{Source of Support: Nil Conflict of Interest: None Declared}

How to cite this URL: Himani Gupta et al: A Conceptual Review On Treatment Modalities For Raktapradar W.S.R. To D.U.B.. International Ayurvedic Medical Journal \{online\} 2021 \{cited December 2021\} Available from: http://www.iamj.in/posts/images/upload/3038_3048.pdf 